\title{
IEAATOTUKA
}

УДК [378.011.3-051:81'243]:005.963

DOI https://doi.org/10.24919/2308-4863/34-5-30

\begin{abstract}
Наталія СКІБА,
orcid.org/0000-0002-3899-3189

кандидат педагогічних наук,

дочент кафедри іноземних мов для природничих факультетів

Львівського начіонального університету імені Івана Франка

(Львів, Україна) nataliamysko@hotmail.com
\end{abstract}

\section{РЕЗУЛЬТАТИ ЕКСПЕРИМЕНТАЛЬНОГО ДОСЛІДЖЕННЯ ЕФЕКТИВНОСТІ МЕТОДИКИ ІНТЕГРОВАНОГО ФОРМУВАННЯ ІНШОМОВНОӤ КОМУНІКАТИВНОЇ ТА МЕТОДИЧНОЇ КОМПЕТЕНТНОСТЕЙ МАЙБУТНІХ ВИКЛАДАЧІВ АНГЛІЙСЬКОЇ МОВИ ДЛЯ ЕКОНОМІЧНИХ СПЕЦІАЛЬНОСТЕЙ}

У статті висвітлено організацію та проведення методичного експерименту з перевірки ефективності методики інтегрованого формування іншомовної комунікативної та методичної компетентностей майбутніх викладачів англійської мови для економічних спеиіальностей. Здійснено аналіз та наведено характеристику отриманих результатів експериментального навчання. Описано способи перевірки валідності отриманих показників рівнів сформованості згаданих компетентностей.

У прочесі експерименту були використані теоретичні та емпіричні методи дослідження, а також методи спостереження, анкетування, тестування, методи математичної статистики для опрацювання результатів. Методичний експеримент охоплював чотири етапи: організаційний, доекспериментального оцінювання, експериментального навчання і післяекспериментального оцінювання та здійснювався за участю студентів магістратури Тернопільського національного педагогічного університету імені Володимира Гнатюка.

Висунуто гіпотезу дослідження, що досягти високого рівня сформованості іншомовної комунікативної та методичної компетентностей у студентів магістратури можливо за умов грунтування методики на засадах компетентнісного, інтегрованого, комунікативно-діяльнісного та рефлексивного підходів; урахування комплексу загальнодидактичних (системної єдності, індивідуальності, суб'єктності) і методичних принципів (комунікативності, ситуативності, новизни, паралельного формування знань, навичок $i$ вмінь, урахування навчальних потреб та інтересів студентів); урахування відповідного навчального матеріалу, визначеного критеріями відбору; використання спеціально розробленої системи вправ $і$ завдань; поетапності представлення викладачем $i$ засвоєння студентами навчального матеріалу.

За допомогою використання комплексу методів математичної статистики на основі обрахунку кількісних показників рівнів сформованості іншомовної комунікативної та методичної компетентностей учасників експериментального навчання доведено ефективність експериментальної методики, валідність сформульованої гіпотези методичного експерименту.

Ключові слова: методичний експеримент, гіпотеза дослідження, рівні сформованості, експериментальне навчання, майбутні викладачі.

Nataliia SKIBA, orcid.org/0000-0002-3899-3189

Candidate of Pedagogical Sciences, Associate Professor at the Department of Foreign Languages for Sciences Ivan Franko National University of Lviv (Lviv, Ukraine) nataliamysko@hotmail.com

\section{EXPERIMENTAL RESEARCH RESULTS OF THE EFFICIENCY OF THE METHODOLOGY OF INTEGRATIVE FORMATION OF FOREIGN LANGUAGE COMMUNICATIVE AND METHODOLOGICAL COMPETENCES OF PROSPECTIVE TEACHERS OF ENGLISH FOR ECONOMICS}

The article outlines the process of organization and implementation of the methodological experiment to verify the efficiency of the methodology of integrative formation of foreign language communicative and methodological competences of prospective teachers of English for Economics. The analysis and the characteristics of the received results of experimental training have been given. 
The methods applied to check the validity of the obtained indicators of the levels of developing the aforementioned competences have been described. During the experiment, theoretical and empirical research methods were used, as well as methods of observation, questionnaires, testing, methods of mathematical statistics for processing the results. The methodological experiment covered four stages: organizational, pre-experimental evaluation, experimental training and post-experimental evaluation. It was conducted at the Ternopil Volodymyr Hnatiuk National Pedagogical University involving master's students.

The hypothesis of the research was formulated as follows: achieving a high level of developing the foreign language communicative and methodological competences of master's students is possible under the conditions of basing the methodology on the principles of competence, integrative, communicative activity-based and reflective approaches; considering a set of general didactic principles (system unity, individuality, subjectivity) and methodological ones (communication, situativity, novelty, parallel formation of knowledge, skills and abilities, encountering students'learning needs and interests; considering relevant learning material, defined by the selection criteria; use of a specially designed system of exercises and tasks; step-by-step presentation of learning material by the teacher and its acquisition by students.

Using a group of mathematical statistics methods, based on the calculation of quantitative indicators of the levels of developing the foreign language communicative and methodological competences of the participants of experimental training, the effectiveness of the suggested methodology and the validity of the formulated hypothesis have been verified and confirmed.

Key words: methodological experiment, hypothesis of the research, levels of development, experimental training, prospective teachers.

Постановка проблеми. Інтеграційні процеси, розвиток економічних відносин, зміцнення культурних зв'язків України з іншими державами зумовлюють потребу у висококваліфікованих фахівцях різних галузей з високим рівнем англомовної професійної комунікативної компетентності, які здатні вільно конкурувати на міжнародному ринку праці. Оскільки іншомовна підготовка таких фахівців здійснюється викладачами англійської мови, то особливої актуальності набуває формування професійної компетентності майбутніх викладачів англійської мови за професійним спрямуванням (далі-АМПС), зокрема англійської мови (далі- АM) для економічних спеціальностей.

Аналіз досліджень. Різні аспекти професійної підготовки майбутніх викладачів іноземних мов (далі - IM) досліджено у працях багатьох вітчизняних і зарубіжних науковців. Проблемі формування іншомовної комунікативної компетентності (далі - ІКК) присвячено наукові розвідки Н. Бориско, О. Бочкарьової, Ю. Британ, І. Задорожної, С. Ніколаєвої, О. Тарнопольського, В. Черниш та інші. Дослідження особливостей формування та розвитку методичної компетентності (далі-МК) здійснено у працях К. Безукладникова, О. Бігич, О. Ігни, Н. Майєр, С. Макеєвої, С. Надточевої. Проблеми підготовки викладачів АМПС та їх професійної діяльності розкрито в роботах А. Вотерса, Т. Дадлі-Еванса, П. Мастера, М. Сейнт Джон, Т. Хатчинсона. Однак методика формування ІКК та МК майбутніх викладачів АМПС, зокрема АМ для економічних спеціальностей, ще залишається не досить висвітленою науковцями.

Мета статті - описати проведення експериментальної перевірки ефективності методики інтегрованого формування IКК та МК майбутніх викладачів АМ для економічних спеціальностей, здійснити аналіз отриманих результатів експериментального навчання.

Виклад основного матеріалу. Для перевірки ефективності розробленої методики інтегрованого формування ІКК та МК майбутніх викладачів АМ для економічних спеціальностей було спроектовано, організовано й проведено методичний експеримент, який розглядаємо як організовану спільну діяльність його учасників для вирішення методичної проблеми (Гурвич, 1980: 39-40).

Методичний експеримент охоплював чотири етапи: організаційний, доекспериментального оцінювання, експериментального навчання та післяекспериментального оцінювання. Його проводили у двох експериментальних групах (ЕГ) - ЕГ 1 та ЕГ 2 за участю студентів магістратури спеціальностей 014.02 Середня освіта (Мова і література (англійська), 035.04 Філологія. Германські мови та літератури (переклад включно) (Англійська мова і література) Тернопільського національного педагогічного університету імені Володимира Гнатюка.

Гіпотеза методичного експерименту полягала в можливості досягнення високого рівня сформованості ІКК та МК у студентів магістратури згаданих вище спеціальностей за умови грунтування методики на засадах компетентнісного, інтегрованого, комунікативно-діяльнісного та рефлексивного підходів; урахування комплексу загальнодидактичних (системної єдності, індивідуальності, суб'єктності) та методичних принципів (комунікативності, ситуативності, новизни, паралельного формування знань, навичок і вмінь, урахування навчальних потреб та інтересів студентів); урахування відповідного навчального матеріалу, визначеного критеріями відбору; використання 
спеціально розробленої системи вправ і завдань; поетапності представлення викладачем і засвоєння студентами навчального матеріалу.

На організаційному етапі методичного експерименту було сформульовано його гіпотезу, визначено мету та завдання, розроблено навчально-експериментальні матеріали (анкети для виявлення інтересів та навчальних потреб студентів, матеріали для комплексного тестування, систему вправ і завдань, тематико-часову структуру інтегрованого формування ІКК та МК), обгрунтовано рівні сформованості і критерії оцінювання рівнів сформованості ІКК та МК майбутніх викладачів АМ для економічних спеціальностей, а також проведено анкетування та здійснено відбір учасників експерименту.

3 метою обгрунтованого оцінювання сформованості ІКК та МК майбутніх викладачів АМ для економічних спеціальностей визначено рівні сформованості згаданих компетентностей (низький, нижчий за середній, середній, вищий за середній, автономний), критерії та якісні й кількісні показники сформованості згаданих компетнтностей. Критерії оцінювання ІКК охоплюють правильність вживання економічних термінів, достатній рівень словникового запасу для вирішення конкретного комунікативного завдання, коректність лексичного оформлення висловлювань; правильність вживання граматичних структур, коректність граматичного оформлення висловлювань; правильність вживання мовленнєвих моделей, коректність стилістичного оформлення висловлювань.

Критерії оцінювання МК включають усвідомлення цілей, завдань і стандартів навчання, володіння основними поняттями і категоріями методики навчання АМПС, володіння сучасними методами дослідження в галузі методики навчання АМ та АМПС, володіння принципами і методами аналізу складників процесу навчання АМПС; сформованість методичних навичок i вмінь (комунікативно-навчальних, конструктивно-проектувальних, організаторських, дослідницьких, аналітико-оцінювальних, інформаційно-комунікаційних, адаптивних,мотиваційних, рефлексивних).

Після доекспериментального оцінювання рівня сформованості ІКК та МК у студентів I курсу магістратури - майбутніх викладачів АМ для економічних спеціальностей в межах навчальної дисципліни «Основи методики навчання англійської мови для студентів нефілологічних спеціальностей», розрахованої на 48 академічних годин, було організовано й проведено експериментальне навчання. Учасників розподілено на дві групи (ЕГ 1 та ЕГ 2) по 18 студентів у кожній. Їм було запропоновано два варіанти експериментальної методики, відмінність яких полягала в організації експериментального навчання, а саме у виборі форм організації навчання. Так, у першому варіанті експериментальної методики, реалізованому в ЕГ 1, 48 академічних годин були порівну розподілені між лекційними й практичними заняттями: 24 години лекційних і 24 години практичних занять. Таким чином акцент зміщено на користь практичної підготовки майбутніх викладачів АМ для економічних спеціальностей. У другому варіанті експериментальної методики, реалізованому в ЕГ 2, налічувалося 48 академічних годин. Згідно навчального плану вони були розподілені на 36 годин лекційних і 12 годин практичних занять.

$\mathrm{y}$ процесі експериментального навчання як в ЕГ 1, так і в ЕГ 2 було використано розроблені комплекси вправ і завдань відповідно до розробленої тематико-часової структури з урахуванням внесених коректив щодо вибору форм організації навчальних занять в ЕГ 1. По завершенні навчання проведено післяекспериментальне оцінювання рівнів сформованості ІКК та МК учасників методичного експерименту обох експериментальних груп. 3 метою визначення рівнів сформованості згаданих компетентностей використано ті ж види завдань, що й на етапі доекспериментального оцінювання, застосовано ті ж критерії і шкали кількісних показників критеріїв.

Ефективність експериментальної методики, валідність гіпотези методичного експерименту доведено за допомогою використання комплексу методів математичної статистики на основі обрахунку кількісних показників рівнів сформованості ІКК та МК учасників експериментального навчання, отриманих в результаті доекспериментального (зріз 1) та післяекспериментального (зріз 2) оцінювання.

У результаті визначення кількісних показників рівнів сформованості ІКК та МК студентів ЕГ 1 та ЕГ 2 за даними зрізу 1 та зрізу 2 сформовано вибірки ЕГ 1 та ЕГ 2. Насамперед необхідно перевірити нормальність розподілу в наших вибірках. Оскільки в нас $є 18$ спостережень у кожній групі і 36 спостережень загалом, крім графічних методів перевірки на нормальність розподілу, а саме частотної гістограми і діаграми розмаху, було вирішено провести тести Колмогорова-Смірнова, Лілієфорса і Шапіро-Вілка (Фоміна, Жиганов, 2017). Після цього було обраховано один із критеріїв встановлення статистичної значущості відмінності двох залежних вибірок: t-критерій Стьюдента для залежних вибірок (якщо розподіл нормальний) і критерій Вілкіксона (якщо розпо- 
діл ненормальний) (Садовий, 2012; Сидоренко, 2000). Всі обрахунки виконані з використанням програмного забезпечення Statistica та Excel.

Представимо розрахунки по ЕГ 1 за кількісними показниками сформованості у студентів ІКК. Так, на рис. 1 зображено гістограму, яка не відповідає теоретично нормальній кривій Гауса, що може свідчити про ненормальність розподілу кількісних показників рівня сформованості ІКК студентів ЕГ 1 за даними зрізів 1 і 2. Критерії Шапіро-Вілка і Лілієфорса (рис. 1) свідчать про ненормальність розподілу, проте критерій Колмогорова-Смірнова (рис. 1) свідчить про протилежне.
3 урахуванням неоднозначності показників критеріїв Шапіро-Вілка, Лілієфорса і Колмогорова-Смірнова здійснено додаткову перевірку на нормальність розподілу методом зображення діаграми розмаху для кількісних показників сформованості ІКК відразу у двох експериментальних групах. Ця перевірка показала несиметричний діапазон нормальних значень, що також свідчить про ненормальність розподілу кількісних показників рівнів сформованості ІКК студентів ЕГ 1 i ЕГ 2 на основі даних зрізів 1 і 2.

Оскільки розподіл значень кількісних показників рівнів сформованості ІКК $є$ ненормальним,

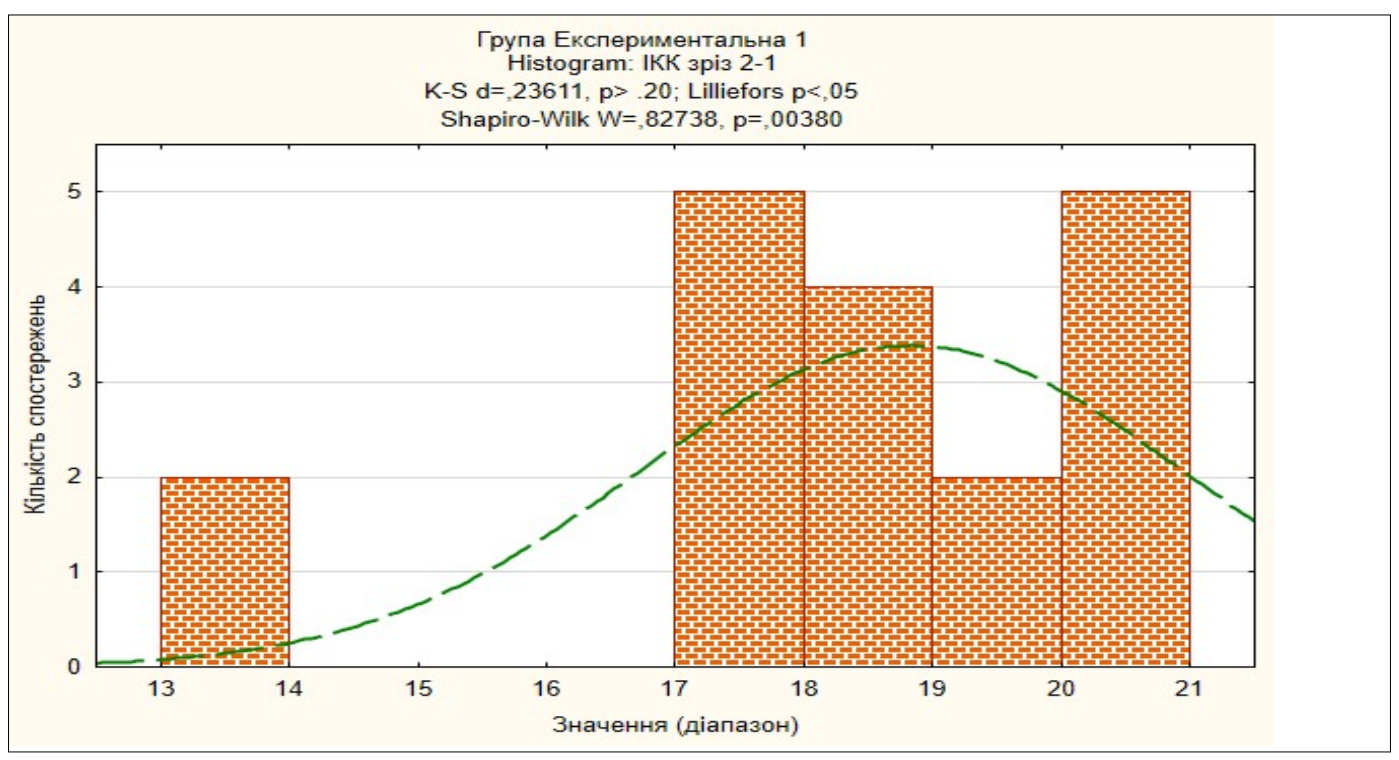

Рис. 1. Гістограма розподілу кількісних показників рівня сформованості ІКК за даними зрізів 1 і 2 в ЕГ 1 обрахованими критеріями Колмогорова-Смірнова, Лілісфорса і Шапіро-Вілка

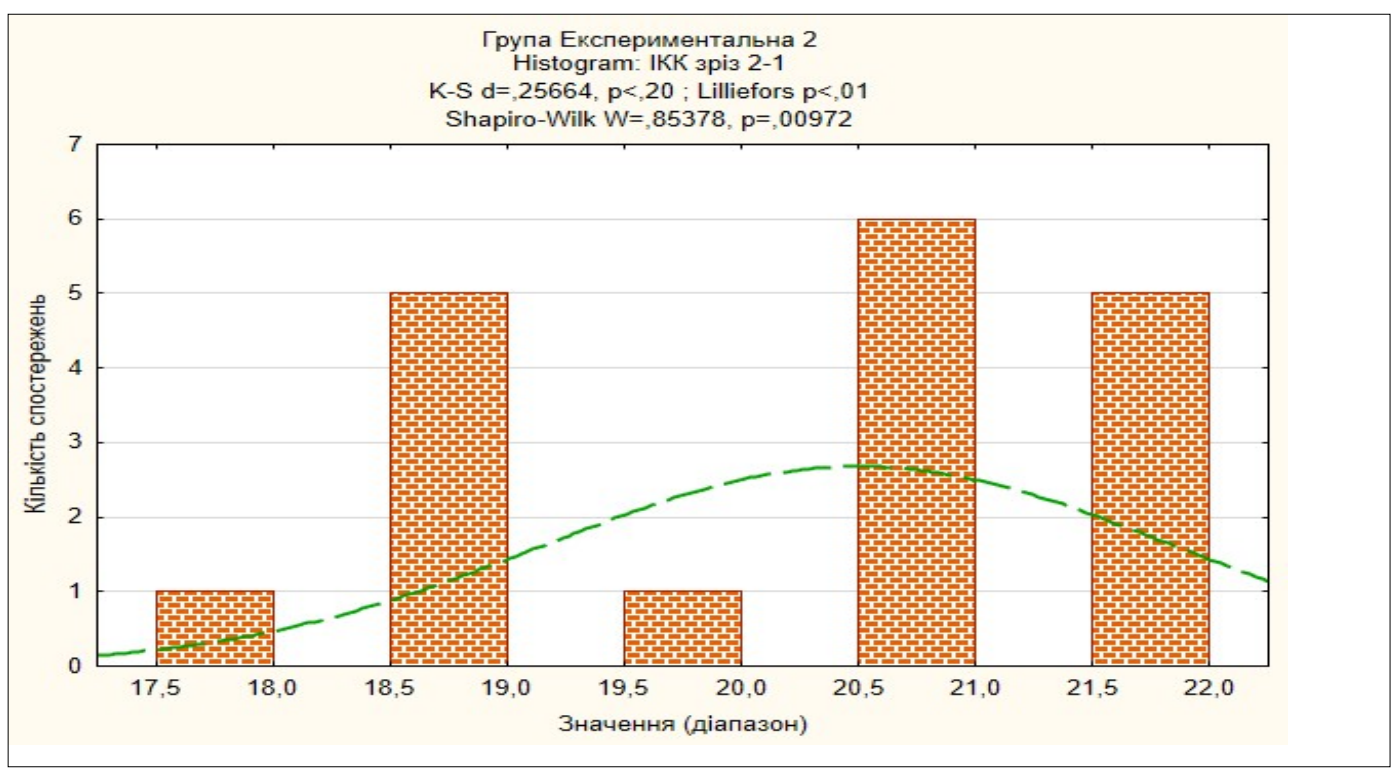

Рис. 2. Гістограма розподілу кількісних показників рівня сформованості ІКК за даними зрізів 1 і 2 в ЕГ 2 обрахованими критеріями Колмогорова-Смірнова, Лілієфорса і Шапіро-Вілка 
то для встановлення статистичної значущості різниці між кількісними показниками рівнів сформованості ІКК між даними зрізів 1 і 2 (тобто доекспериментального і післяекспериментального оцінювання) було здійснено обрахунок критерію Вілкіксона. Це дозволило встановити статистичну значущість різниці між кількісними показниками рівнів сформованості ІКК та даними зрізів 1 і 2, що свідчить про значне зростання кількісних показників рівнів сформованості ІКК студентів ЕГ 1 за період експериментального навчання.

Беручи до уваги відмінність показників критерію Колмогорова-Смірнова, для більшої достовірності результатів експерименту в цьому випадку було прийняте рішення обчислити як непараметричний, так і параметричний критерії. Прийнято рішення обрахувати парний t-критерій Стьюдента як параметричний. Парний t-критерій Стьюдента для кількісних показників рівнів сформованості ІКК за період експериментального навчання в ЕГ 1 також встановив статистичну значущість різниці між зрізами 1 і 2, тому можна стверджувати про статистичну значущість зростання кількісних показників рівнів сформованості ІКК за період експериментального навчання. На основі здійснених обрахунків критерію Вілкіксона та парного t-критерію Стьюдента можна стверджувати про значне зростання кількісних показників рівнів сформованості ІКК за період експериментального навчання в ЕГ 1, що свідчить про ефективність першого варіанту експериментальної методики.

Здійснимо обрахунки нормальності розподілу кількісних показників рівнів сформованості ІКК студентів ЕГ 2. Рис. 2 демонструє, що гістограма не відповідає теоретично нормальній кривій Гауса. Як і на збудованій для ЕГ 1 і ЕГ 2 діаграмі розмаху, можна спостерігати несиметричний діапазон нормальних значень, що також свідчить про ненормальність розподілу кількісних показників рівнів сформованості ІКК в ЕГ 2. Критерії ШапіроВілка, Лілієфорса і Колмогорова-Смірнова (рис. 2) також свідчать про ненормальність розподілу.

3 урахуванням однозначності графічних методів встановлення нормальності розподілу, а також показників критеріїв Шапіро-Вілка, Лілієфорса і Колмогорова-Смірнова для встановлення статистичної значущості різниці між кількісними показниками рівнів сформованості ІКК студентів ЕГ 2 за період експериментального навчання за даними зрізів 1 і 2 здійснено обрахунок лише непараметричного критерію Вілкіксона. На основі здійснених обрахунків можна стверджувати про значне зростання кількісних показників рівнів сформованості ІКК за період експериментального навчання в ЕГ 2, що свідчить про ефективність другого варіанту експериментальної методики.

Здійснимо подібні обрахунки і для виявлення зростання кількісних показників рівня сформованості МК учасників методичного експерименту. Насамперед з'ясуємо нормальність розподілу кількісних показників рівня сформованості МК студентів ЕГ 1. На рис. 3 можна спостерігати, що діаграма не відповідає теоретично нормальній кривій Гауса, що може свідчити про ненормальність розподілу. Критерії Шапіро-Вілка і Лілієфорса (рис. 3) свідчать про ненормальність роз-

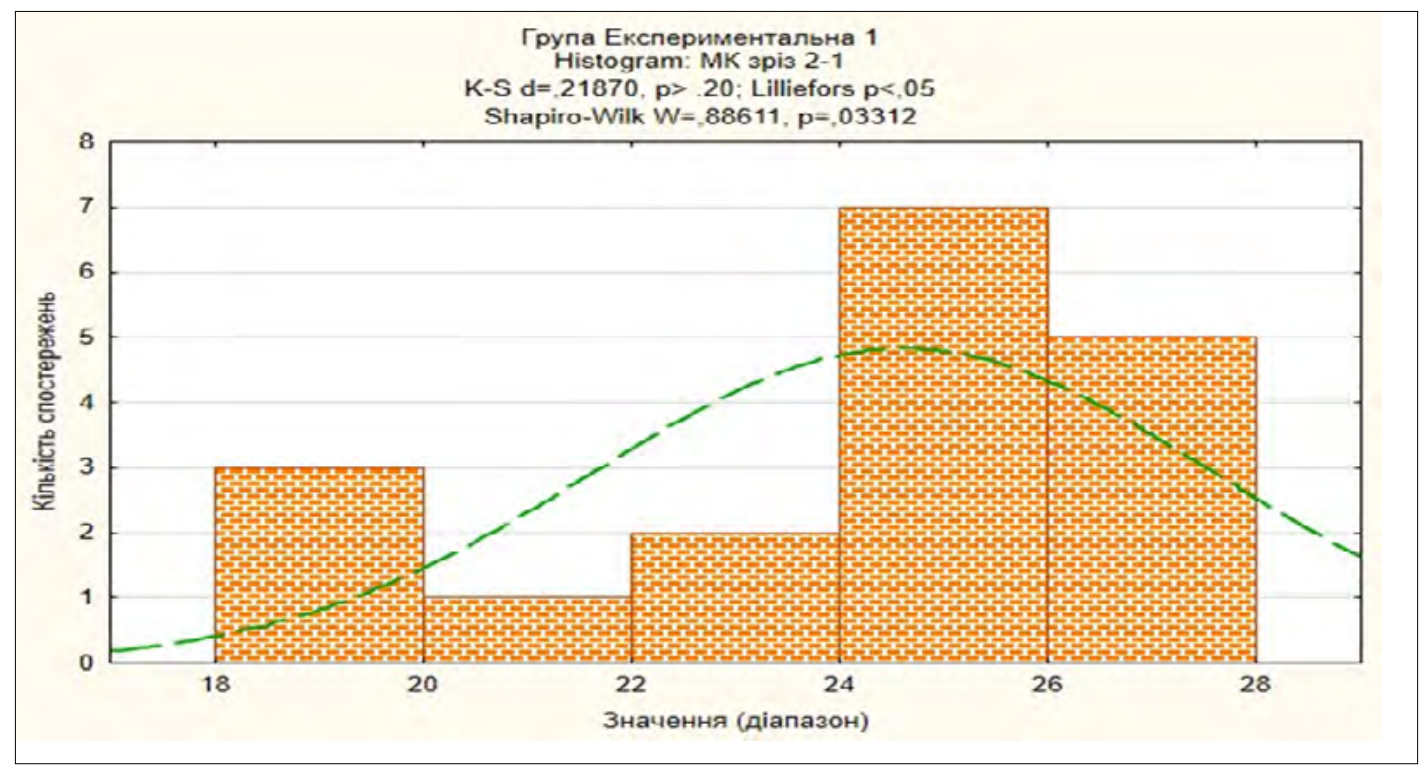

Рис. 3. Гістограма розподілу кількісних показників рівня сформованості МК за даними зрізів 1 і 2 в ЕГ 1 з обрахованими критеріями Колмогорова-Смірнова, Лілієфорса і Шапіро-Вілка 
Скіьа Н. Резумьтати експериментального дослідження ерективності ...

поділу, проте критерій Колмогорова-Смірнова (рис. 3) знову свідчить про протилежне.

Діаграма розмаху кількісних показників рівнів сформованості МК за даними доекспериментального й післяекспериментального оцінювання в ЕГ 1 і ЕГ 2 показала несиметричний діапазон нормальних значень для показників ЕГ 1 і симетричний діапазон нормальних значень для показників ЕГ 2, що свідчить про ненормальність розподілу кількісних показників рівнів сформованості МК у студентів ЕГ 1 і нормальність розподілу кількісних показників рівнів сформованості МК у студентів ЕГ 2.

Для більшої достовірності результатів експерименту в цьому випадку було прийнято рішення обчислити як параметричний, так і непараметричний критерії. Критерій Вілкіксона встановив статистичну значущість різниці між даними доекспериментального (зріз 1) і післяекспериментального (зріз 2) оцінювання, тобто дозволив встановити статистичну значущість зростання рівня сформованості МК у студентів ЕГ 1 за період експериментального навчання.

Парний t-критерій Стьюдента також встановив статистичну значущість різниці між даними зрізів 1 і 2 в ЕГ 1 щодо зростання кількісних показників рівня сформованості МК, тобто дозволив стверджувати про ефективність експериментального навчання щодо зростання рівня сформованості МК у студентів ЕГ 1. Здійснені комплексні обрахунки дозволили зробити висновок про статистичну значущість зростання кількісних показників рівнів сформованості МК у студентів ЕГ 1 за період експерименталього навчання. Ідентичні обрахунки здійснено й щодо кількісних показників рівня сформованості МК у студентів ЕГ 2.

Перевірка на нормальність розподілу кількісних показників рівня сформованості МК у студентів ЕГ 2 теж дала результати. Так, на рис. 4 можна побачити, що гістограма загалом відповідає теоретично нормальній кривій Гауса, що може свідчити про нормальність розподілу. На діаграмі розмаху кількісних показників рівнів сформованості МК можна спостерігати симетричний діапазон нормальних значень для кількісних показників рівнів сформованості МК у студентів ЕГ 2, що також свідчить про нормальність розподілу. Критерії Шапіро-Вілка, Лілієфорса і Колмогорова-Смірнова (рис. 4), що свідчать про нормальність розподілу.

3 урахуванням нормальності розподілу кількісних показників рівня сформованості МК в ЕГ 2 обчислено парний t-критерій Стьюдента, який встановив статистичну значущість різниці між даними доекспериментального і післяекспериментального оцінювання, тобто даними зрізів 1 i 2. Можна стверджувати про статистичну значущість зростання кількісних показників рівнів сформованості МК у студентів ЕГ 2 за період експерименталього навчання.

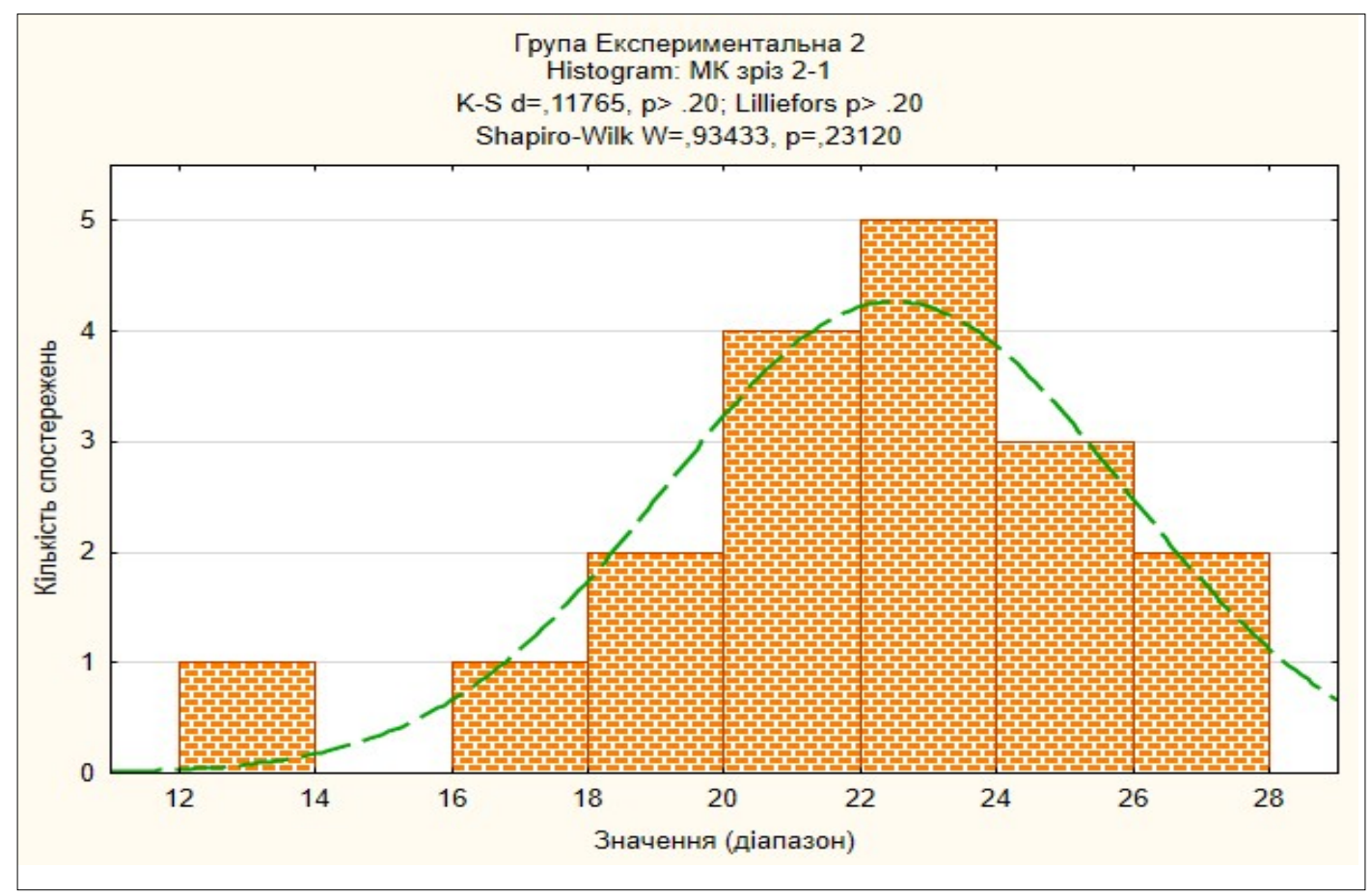

Рис. 4. Гістограма розподілу кількісних показників рівня сформованості МК за даними зрізів 1 і 2 в ЕГ 2 з обрахованими критеріями Колмогорова-Смірнова, Лілієфорса і Шапіро-Вілка 
Встановлено, що як в ЕГ 1, так і в ЕГ 2 відмінність між кількісними показниками рівня сформованості ІКК й МК за даними доекспериментального і післяекспериментального оцінювання $\epsilon$ статистично значущою. При цьому середній бал кількісних показників рівнів сформованості ІКК студентів як ЕГ 1, так і ЕГ 2 за період експериментального навчання сумарно зріс на $85 \%$. Цей показник у відсотковому співвідношенні обраховувався на основі результатів доекспериментального і післяекспериментального оцінювання, тобто за даними зрізів 1 і 2 за кількісними показниками рівнів сформованості ІКК студентів в ЕГ 1 і ЕГ 2.

Середній бал кількісних показників рівнів сформованості МК студентів ЕГ 1 і ЕГ 2 за період експериментального навчання сумарно зріс на $125 \%$. Як і у попередньому випадку показник у відсотковому співвідношенні обраховувався на основі даних доекспериментального і післяекспериментального оцінювання, тобто за даними зрізів 1 і 2 (рис. 5) за кількісними показниками рівнів сформованості МК студентів в ЕГ 1 і ЕГ 2.

Експериментальна методика інтегрованого формування ІКК та МК у майбутніх викладачів АМ для економічних спеціальностей загалом довела свою ефективність у двох експериментальних групах. 3 метою виявлення того, який із варіантів експериментальної методики довів більшу ефективність у процесі експерименталь- ного навчання, здійснено аналіз відсоткового показника зростання середнього балу для рівня сформованості ІКК і МК окремо у студентів ЕГ 1 і у студентів ЕГ 2 (рис. 6).

Середній бал відсоткового показника зростання рівня сформованості ІКК у студентів ЕГ 1 склав $90 \%$, МК - 150\%. Середній бал відсоткового показника зростання рівня сформованості ІКК у студентів ЕГ 2 склав 80\%, МК - 100\%. Отримані дані свідчать про ефективність експериментальної методики інтегрованого формування IКК і МК майбутніх викладачів АМ для економічних спеціальностей в обох варіантах методики, проте вища ефективність експериментального навчання виявлена в ЕГ 1 за першим варіантом експериментальної методики, за яким процес інтегрованого формування ІКК та МК майбутніх викладачів АМ для економічних спеціальностей відбувався в умовах організації навчання за однакової кількості лекційних і практичних занять.

Такий спосіб організації експериментального навчання, коли кількість навчального часу, відведена для практичної підготовки майбутніх викладачів АМ, відповідає або й перевищує кількість навчального часу, відведеного для їхньої теоретичної підготовки, сприяє активному розвитку у студентів відповідних навичок і вмінь, які $\epsilon$ складниками ІКК та МК, у процесі виконання розроблених ізапропонованих комплексів вправ ізавдань.

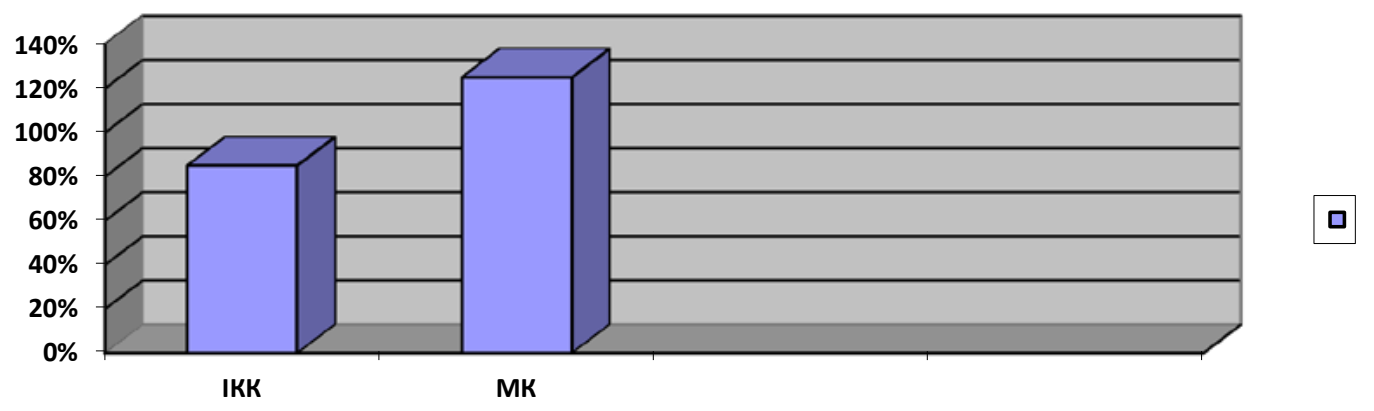

Рис. 5. Гістограма відсоткового зростання середнього балу кількісних показників ІКК та МК у студентів ЕГ 1 і ЕГ 2 за період експериментального навчання

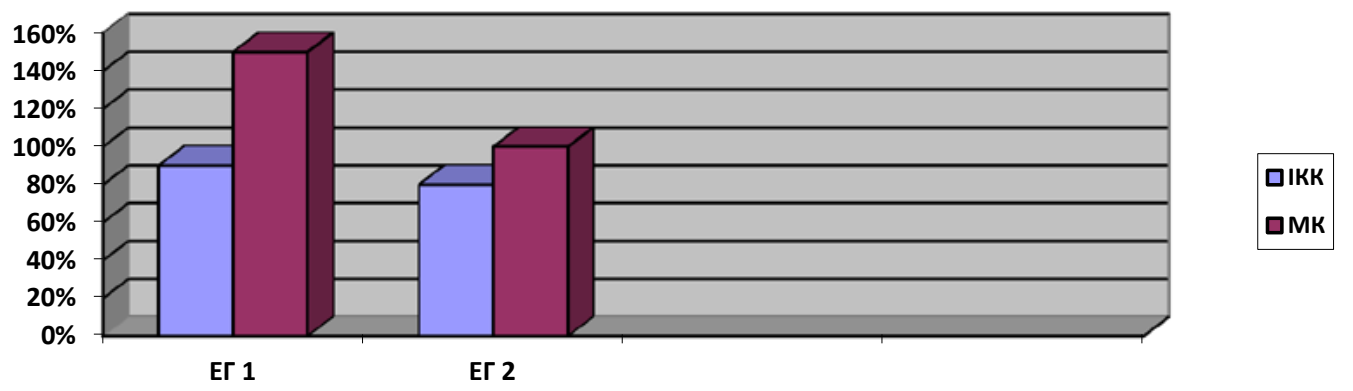

Рис. 6. Відсоткові показники зростання середнього балу для рівнів сформованості ІКК і МК в ЕГ 1 і ЕГ 2 
Висновки. Здійснена інтерпретація результатів методичного експерименту дозволяє зробити висновок про валідність гіпотези методичного експерименту, яка полягає в досягненні високого рівня сформованості у студентів магістратури спеціальностей 014.02 Середня освіта (Мова і література (англійська), 035.04 Філологія. Германські мови та літератури (переклад включно) (Англійська мова і література) IКК та МК за умови грунтування експериментальної методики на засадах компетентнісного, інтегрованого, комунікативнодіяльнісного та рефлексивного підходів; урахування комплексу загальнодидактичних (системної єдності, індивідуальності, суб'єктності) та мето- дичних принципів (комунікативності, ситуативності, новизни, паралельного формування знань, навичок і вмінь, урахування навчальних потреб та інтересів студентів, які відповідають визначеним критеріям відбору навчального матеріалу; використання спеціально розробленої системи вправ і завдань; поетапності представлення викладачем і засвоєння студентами навчального матеріалу. 3 урахуванням даних про ефективність експериментальної методики інтегрованого формування ІКК та МК майбутніх викладачів АМ для економічних спеціальностей вважаємо доцільним формулювання методичних рекомендацій щодо згаданих компетентностей.

\section{СПИСОК ВИКОРИСТАНИХ ДЖЕРЕЛ}

1. Гурвич П. Б. Теория и практика эксперимента в методике преподавания иностранных языков. Владимир : Владимирский гос. пед. ин-т, 1980. 103 с.

2. Садовий М. І. Особливості педагогічного експерименту у дисертаційних дослідженнях. Наукові записки Кіровоградського державного педагогічного університету ім. Володимира Винниченка. Педагогічні науки. Кіровоград, 2012. Вип. 106. С. 110-120.

3. Сидоренко Е. В. Методы математической обработки в психологии. Санкт-Петербург : Речь, 2000. 350 с.

4. Скіба Н. Я. Інтегроване формування іншомовної комунікативної та методичної компетентностей майбутніх викладачів англійської мови для економічних спеціальностей : дис. канд. пед. наук: 13.00.02. Тернопіль, 2019. 337 с.

5. Фомина Е. Е., Жиганов Н. К. Математические методы анализа данных в социологии с использованием пакетов MS Excel и STATISTICA : учебное пособие. Тверь : РИЦ ТвГТУ, 2017. 167 с.

\section{REFERENCES}

1. Gurvich P. B. Teoriya i praktika eksperimenta v metodike prepodavaniya inostrannyih yazyikov [Theory and practice of experiment in the methodology of teaching foreign languages]. Vladimir : Vladimir State pedagogic institute, 1980. $103 \mathrm{p}$. [in Russian].

2. Sadovyi M. I. Osoblyvosti pedahohichnoho eksperymentu u dysertatsiinykh doslidzhenniakh [Features of pedagogical experiment in dissertation researches]. Scientific notes of Volodymyr Vynnychenko Kirovograd State Pedagogical University. Pedagogical sciences. Kirovograd, 2012. Vyp. 106. P. 110-120 [in Ukrainian].

3. Sidorenko E. V. Metodyi matematicheskoy obrabotki v psihologii [Methods of mathematical processing in psychology]. St. Petersburg : Rech, 2000. 350 p. [in Russian].

4. Skiba N. Ya. Intehrovane formuvannia inshomovnoi komunikatyvnoi ta metodychnoi kompetentnostei maibutnikh vykladachiv anhliiskoi movy dlia ekonomichnykh spetsialnostei [Integrative formation of foreign language communicative and methodological competences of prospective teachers of English for economics]. Candidate's thesis. Ternopil, 2019.337 p. [in Ukrainian].

5. Fomina E. E., Zhiganov N. K. Matematicheskie metodyi analiza dannyih $\mathrm{v}$ sotsiologii s ispolzovaniem paketov MS Excel i STATISTICA [Mathematical methods of data analysis in sociology using MS Excel and STATISTICA packages]. Tver : Tver State Technical University, 2017. 167 p. [in Russian]. 